\title{
Impact of fertilizer combinations on malformation physiology of mango panicles (Mangifera indica. $\mathrm{L}$ ) $\mathrm{cv}$. Dusheri
}

\author{
Muhammad Azam ${ }^{*}$, Rashad Qadri ${ }^{1}$, Muhammad Imran Khan ${ }^{2}$, \\ Mumtaz Khan ${ }^{3}$, Naheed Akhtar ${ }^{4}$, Nazar Hussain Khan ${ }^{5}$ and \\ Chaudhary Muhammad Ayyub ${ }^{1}$ \\ 1. Institute of Horticultural Sciences, University of Agriculture, Faisalabad-Pakistan \\ 2. Institute of Soil and Environmental Sciences, University of Agriculture, Faisalabad-Pakistan \\ 3. Department of Soil and Environmental Sciences, Gomal University, DIK-Pakistan \\ 4. Horticulture Research Sub Station Dera Ghazi Khan-Pakistan \\ 5. Department of Continuing Education, University of Agriculture, Faisalabad-Pakistan \\ *Corresponding author's email: muhammad.azam@uaf.edu.pk \\ Citation
}

Muhammad Azam, Rashad Qadri, Muhammad Imran Khan, Mumtaz Khan, Naheed Akhtar, Nazar Hussain Khan and Chaudhary Muhammad Ayub. Impact of fertilizer combinations on malformation physiology of mango panicles (Mangifera indica. L) cv. Dusheri. Pure and Applied Biology. Vol. 9, Issue 1, pp626-634. http://dx.doi.org/10.19045/bspab.2020.90068

\begin{tabular}{llll}
\hline \hline Received: 20/08/2019 & Revised: 25/10/2019 & Accepted: 15/11/2019 & Online First: 20/12/2019 \\
\hline \hline
\end{tabular}

\section{Abstract}

Mango malformation is destructive malady in mango producing countries and causing significant economic loss. The present/This study was undertaken to evaluate the effect of different combinations of N, P and K on incidence of malformation physiology of mango (Mangifera Indica. L) Cv. Dusheri. Each treatment of N (1000 g), P (750 g) and K (750 g) was soil applied during February and August to investigate time of flush emergence, malformation frequency and morphological parameters. Results revealed that the minimum number of malformed panicles and higher number of healthy panicles was observed in NPK treated plant. In addition, NPK treated plant exhibited higher length of healthy panicles. Moreover, NPK treatment showed lowest malformation intensity percentage as compared to other fertilizer treatments. The results regarding regrowth pattern of shoots after pruning showed that overall maximum percentage of such terminals remained pruned $(93.59 \%)$ while some of its produced vegetative flushes (2.19\%). However, alone or combine fertilizer application cannot control this malady. The present study, therefore, suggests proper and regular implementation of pruning practice to control this malady.

Keywords: Malformation; Mango; N, P and K fertilizer; Soil application

\section{Introduction}

Mango (Mangifera indica. L) is considered as king of fruits and praised due to its unique taste and aroma among the peoples. Its export demand has been significantly increased in international market -. However, mango industry is facing a serious disorder "mango malformation" in the orchards which is decreasing the production, quality of fruit and productive life in different countries. 
Several studies have reported about the etiology of mango malformation which may be associated with different biotic and abiotic factors, viruses, fungus, nutritional imbalances and mites (Rymbai and Rajesh, 2011).

Two types of malformation are recorded such as vegetative and floral malformation. Vegetative malformation is less observed, while bearing mango plants shows more floral malformation [1]. Malformed inflorescences are short, fail to produce fruits which ultimately reduced the yield which is great economic loss. Depending upon the severity of disease, crop production may limit by $50-60 \%$ and in some sever cases $100 \%$ in the orchards [2, 3]. However, malformed parts showed the presence of the fungus (fusarium moniliforme var. Subglutinans), and mycelial growth was noted during different bud development stages under electron microscopy [4]. Fungicide were used but remain failed to control this malady [5]. Malformed shoots removal reported to be effective method to control this widespread disease in the commercial orchards [6].

Although, mango is grown throughout the world, while high production is limited in few countries [7]. Mango is successfully cultivated on a large area in Pakistan. After citrus, it is second largest commercial fruit of the country and is cultivated over an area of 156.6 thousand hectares, contributing about $15.77 \%$ of the total fruit area (1753.9 thousand hectares) of the country Anon [8]. It is exported in different countries and earn foreign exchange. Climatic conditions are favorable for proper mango cultivation, production and good quality. However, mango malformation is an emerging threat to mango industry which is causing great economic loss to farmers.

Numerous researchers have reported that malformation is endemic and common disease in major mango growing countries throughout the world
[9-13]. Malformation is widespread disease and was first time reported 120 years back from Darbhanga district Bihar by Maries [14] and never recovers in infected tree [15]. Yield losses cannot be accurately measured due to no linear relationship with the severity of disease [16]. However, branches with malformed inflorescences remain unproductive, thus reducing the yield [17]. It has been reported that $86 \%$ decrease in yield occurred during three years. Malformation affected the 50\% trees and caused sever yield losses in northern India mango orchards, as well as significant effects has been reported in Egypt [18]. Moreover, 73\% mango farms have reported malformation severity from 1 to $70 \%$ in South Africa [19]. Despite of consistent research on this issue, no effective control of this disease has been found [20-22]. Young mango cv. Totapuri showed higher fruit yield and TSS with nitrogen application, while $P$ and $K$ showed non-significant results [23]. Fertilizer application of 400 $\mathrm{N}, 125 \mathrm{P}, 440 \mathrm{~K}, 40 \mathrm{Mg}$, and $80 \mathrm{~S}$ (g/tree/year) significantly improved yield and quality of mango in Guangdong, China [24]. Higher number of fruits/plant, yield, pulp content and fruit quality improved with the application of $\mathrm{N}, \mathrm{P}$, and $\mathrm{K}$ in West Bengal, India [25]. Higher fruit weight and yield were recorded with the application of urea at 500 or $1000 \mathrm{~g}$ $\mathrm{N} /$ tree and potassium sulfate at $400 \mathrm{~g}$ $\mathrm{K} 2 \mathrm{O} /$ tree [26]. Higher dose of $\mathrm{K}$ fertilizer along with other manures were applied in three splits doses, and improved the leaf and fruit characteristics, total acidity, Vit. C, TSS and total sugar content on mango cv. Mabrouka, Egypt [27-28].

There are several factors such temperature, age of tree, time, nutrional status and susceptibility of cultivars that may affect the incidence of malformation. Some studies reported that deficiency of micronutrient and 
macronutrient may or may not be associated with the extent of malformation. Nutrient insufficiency in mango orchards may or may not be regarded as basic reason of this malady [29]. It has been observed that malformed panicles had higher level of nitrogen than healthy panicles [30]. However, NPK application (9:3:3) did not reduce the incidence of malformation and such nutritional imbalance that is not directly related, nevertheless, may enhance the occurrence of this disease [31]. Higher $N$ application reduces the malformation, whereas $\mathrm{P}$ and $\mathrm{K}$ addition significantly increases malformation [15]. Therefore, proper amount and type of fertilizer at proper time play a vital role in increasing average yield per hectare. However, there is lack of proper information on effect of nutrition in malformation. In this study, different fertilizer combinations were applied during different months to investigate their effect on incidence of malformation. Therefore, the present studies were conducted to investigate the morphological characteristic of healthy and malformed panicles and malformation intensity of mango $\mathrm{cv}$. Dushari.

\section{Materials and methods}

The present study regarding the malformation physiology of mango (Mangifera indica. L) cv. Dusheri. panicles regulated by $\mathrm{N}, \mathrm{P}$ and $\mathrm{K}$ fertilizers, applied singly and in combination, was carried out during February and August months N, P and K were applied @ 1000g, 750g and 750g, respectively. $\mathrm{N}$ was applied in the form of Urea, $\mathrm{P}$ through Triple Super Phosphate (TSP) while K was supplied in the form of (SOP) Sulphate of Potash (Table 1). Fertilizers were applied in February and August. Amount of fertilizer for each treatment was calculated according to the said quantity of each element. Experimental material used in fieldwork consisted of 16 , twelve- to fifteen-years-old, healthy trees of mango cv. Dusheri. The research work reported in this manuscript was conducted at fruit Experimental Orchard Sq. No. 9, Institute of Horticultural Sciences, University of Agriculture, Faisalabad during 2009-2010. All the treated mango trees received similar cultural practices. Time of flushes were noted when the first flush emerges on the mango tree and till the last one. Malformation frequency was noted regarding the healthy and malformed number of panicles by the method [32]. A frame of size $(2 \mathrm{~m} \times 1 \mathrm{~m})$ was used on the four sides such as East, West, North, South on the middle height of the canopy of a tree. Total number of healthy and malformed panicles were counted and averaged. Morphological dimensions of healthy and malformed panicles (length and width) were measured with measuring tap (Stanley powerlock 25). Malformation intensity was recorded as described by Khan and Khan (1966). Healthy and malformed inflorescence were calculated for the determination of malformation intensity.

$\mathrm{I}=\mathrm{M} \times 100 / \mathrm{T}$

$\mathrm{M}=$ Malformed inflorescence

$\mathrm{T}=$ Total inflorescence in the sampler

$\mathrm{I}=$ Intensity, percentage of the diseased inflorescence

The data were collected and subjected to statistical techniques by using Statistix 8 (version 8.1) software for analysis of variance techniques by using Least Significant Difference (LSD) test at a level of 5\% significance $(p \leq 0.05)$.

\section{Results and discussion}

\section{Effect on time of flush emergence}

Time of flush emergence during different months was observed. From the observations, it was found nonsignificant effect of fertilizer application on the early or delayed emergence of flushes (Table 2). In the same way, observations did not confirm the findings of Marloth [33] that adequate supply of nitrogen induced early flush of 
vegetative growth, which encouraged flowering in litchi.

Effect on time of emergence of malformed panicle and malformation frequency

Time of emergence of malformed panicles were usually started in midDecember and continue till the first week of February in treated and control plant (Table 3). Malformed panicles were observed maximum in T1 plant, while minimum was observed in T8. In addition, T8 treated plant exhibited higher number of healthy panicles, while lower number of healthy panicles was found in T7 (Table 4). It has been reported that foliar application of low biuret urea increased leaf $\mathrm{N}$ level, as well as the intensity of malformation [34].

Effect on length of healthy panicle (cm)

The result revealed that average length of healthy panicle was affected by the different combinations of fertilizers. Maximum length of healthy panicle was observed highly significant in T8 treated plant (Table 5). With the interaction of fertilizer T6 was found higher length of healthy panicle as compared to T5 and PK. Among single application of fertilizer, T2 had higher length which was closely followed by the T3, T4 and control.

Effect on width of healthy panicle (cm) The data showed that application of different fertilizers showed significant results regarding the width of healthy panicles. However, higher width of panicle was found in T8 (Table 5). When fertilizer applied singly, lower width was recorded in T3. When studied the interaction of different fertilizers, T6 showed higher width followed by T5 and T7, respectively. Minimum width of healthy panicle was recorded in the control.

\section{Effect on length of malformed panicle (cm)}

Length of malformed panicle were also measured after application of different fertilizer combinations. It was found that maximum lengths of malformed panicle were found in T1, whereas T3, T2 and T4 treatments also had closely similar results. However, minimum length was recorded in T8 treated plant (Table 5).

Effect on width of malformed panicle (cm)

The results regarding the width of malformed panicle was found higher T1, while lower width was recorded in T8 (Table 5). However, some trees showed slight differences in width of malformed panicle in some treatments.

\section{Effect on malformation intensity (\%)}

Mango malformation is serious malady and destructive disease which causing significant economic loss in in mango producing countries [35]. It is ubiquitous present and destructive due to its etiology and still farmers are not fully successful to control and understand this disease. Alone, proper fertilizer application cannot control the malformation diseased because it is complex disorder.

There were remarkably significant differences with the application of different fertilizers combination on the control of malformation intensity. The highest malformation intensity was found in the control. Whereas, T8 treatment showed lowest malformation intensity percentage. The results of malformation intensity were found similar to the treatments $\mathrm{T} 7, \mathrm{~T} 4$ and $\mathrm{T} 5$, respectively (Table 5). These result are in similar with Prasad [36] who found that nutrition plays an important role in reducing the incidence of malformation. Application of $\mathrm{N}, \mathrm{P}$ and $\mathrm{K}$ in the ratio of 9:3:3 reduced the incidence of the floral malformation. It has been observed that in mango increased nitrogen level through spray on otherwise reduced the proportion of affected panicles [37].

Fertilizer with different combination N, NK or NP treatments reduces the incidence of malformation of the inflorescence in the cultivar Bombay Alphonso [38]. It has been depicted that 
in cv. Langra, incidence of floral malformation was the lowest (20\%) when treat with rogar, multiplex and urea (insecticide, trace elements and $\mathrm{N}$ fertilizer respectively) and the highest $(55 \%)$ in non-treated trees [39]. During fruit development at pea stage, malformed shoots removed and found $60-79 \%$ reduction of malady in the next year. It has been noted that control of disease was variable in different varieties [40].

Effect on regrowth pattern of malformed panicle

Regarding regrowth of pruned malformed panicles during next year, overall maximum percentage of such terminals remained pruned $(93 \%)$ while some of its produced vegetative flushes (2\%). Reproductive growth from pruned malformed sites was $3 \%$ in which malformed panicles were $1 \%$ and healthy panicles were $1 \%$. The significant results were obtained and it was assumed that there was no relationship between the treatments but as minimum number of malformed panicles emerged in the T3, T7 and T6 treatments. Maximum number of malformed panicles emerged in the T5. While more percentage of healthy panicles was found in the T5 followed by
T8 and T4 treatments. Minimum number of healthy panicle was found in the T7. More number of vegetative shoots emerged from $\mathrm{P}$ followed by $\mathrm{T} 5$ and minimum number of vegetative shoots emerged in the T2 and T7. While percentage of ceased branches were almost same i.e. in the T8 and T2 application (Table 6)

Similar findings were recorded by [37] who founds that increase nitrogen level through spray reduced the percentage of malformed panicles in mango. In this experiment level of nitrogen was suitable to control malformation as observed earlier in studies by [38] reported that the incidence of malformation was found to decrease in plants under $\mathrm{N}, \mathrm{NK}$ or $\mathrm{NP}$ treatments, but increased in plants receiving either $\mathrm{PK}$ or $\mathrm{P}$ alone, which clearly indicated that nitrogen level in leaves is inversely proportional to malformation percentage. These results are not in conformity with the findings of [41] who found significantly higher nitrogen in malformed panicles. Our results are in line with the findings of [42] who reported that foliar spray of $\mathrm{N}$ at monthly intervals during winter significantly reduced malformation.

Table 1. Fertilizer treatments for mango Cv. Dusehri

\begin{tabular}{|c|c|c|c|}
\hline Treatments & Macro Element & Time of application & Amount of fertilizer(s) \\
\hline T1 & Control & & $1000 \mathrm{~g}$ Urea \\
\cline { 2 - 4 } T2 & $\mathrm{N}$ & February & $1000 \mathrm{~g}$ Urea \\
\hline $\mathrm{T} 3$ & & August & $1500 \mathrm{~g}$ TSP \\
\hline $\mathrm{T} 4$ & $\mathrm{P}$ & February & $1500 \mathrm{~g}$ SOP \\
\hline \multirow{2}{*}{$\mathrm{T} 5$} & $\mathrm{KP}$ & February & $1000 \mathrm{~g}$ Urea $+750 \mathrm{~g}$ TSP \\
\cline { 2 - 4 } & & February & $1000 \mathrm{~g}$ Urea $+750 \mathrm{~g}$ TSP \\
\hline \multirow{2}{*}{$\mathrm{T} 6$} & $\mathrm{NK}$ & Fugust & $1000 \mathrm{~g}$ Urea + 750g SOP \\
\cline { 2 - 4 } & & Augury & $1000 \mathrm{~g}$ Urea $+750 \mathrm{~g}$ SOP \\
\hline \multirow{2}{*}{$\mathrm{T} 7$} & $\mathrm{PK}$ & August & $1500 \mathrm{~g}$ TSP+ 1500g SOP \\
\hline \multirow{2}{*}{$\mathrm{T} 8$} & $\mathrm{NPK}$ & February & $1000 \mathrm{~g}$ Urea $+750 \mathrm{~g}$ TSP $+750 \mathrm{~g}$ SOP \\
\cline { 2 - 4 } & & August & $1000 \mathrm{~g}$ Urea $+750 \mathrm{~g}$ TSP + 750g SOP \\
\hline
\end{tabular}


Table 2. Effect of fertilizer combinations on time of flushes emergence

\begin{tabular}{|c|c|c|c|c|c|}
\hline Treatments & April & May & June & July & August \\
\hline T1 (control) & 3 to $19 *$ & $20-28$ & $19-28$ & $18-29$ & $19-30$ \\
\hline T2 (N) & $21-29$ & $21-29$ & $14-23$ & $16-25$ & $18-27$ \\
\hline T3 (P) & $1-18$ & $16-27$ & $19-26$ & $13-22$ & $21-30$ \\
\hline T4 (K) & $3-25$ & $18-26$ & $14-25$ & $14-21$ & $16-27$ \\
\hline T5 (NP) & $2-19$ & $19-27$ & $18-28$ & $11-20$ & $22-28$ \\
\hline T6 (NK) & $2-20$ & $21-29$ & $17-26$ & $17-25$ & $16-29$ \\
\hline T7 (PK) & $3-21$ & $24-30$ & $13-23$ & $16-27$ & $21-29$ \\
\hline T8 (NPK) & $4-31$ & $13-27$ & $13-29$ & $14-28$ & $13-26$ \\
\hline
\end{tabular}

* Unit days

Table 3. Effect of fertilizer combinations on time of emergence of malformed panicles

\begin{tabular}{|c|c|c|}
\hline Treatments & $\mathbf{2 0 1 1}$ & $\mathbf{2 0 1 2}$ \\
\hline T1 (control) & 17 Dec to 12 Jan & 05 Jan to 21 Jan \\
\hline T2 $(\mathrm{N})$ & 03 Jan to 21 Jan & 29 Jan to 10 Fab \\
\hline T3 $(\mathrm{P})$ & 09 Jan to 18 Jan & 23 Jan to 06 Fab \\
\hline T4 $(\mathrm{K})$ & 29 Dec to 13 Jan & 27 Dec to 15 Jan \\
\hline T5 (NP) & 02 Jan to 11 Jan & 19 Dec to 11 Jan \\
\hline T6 $(\mathrm{NK})$ & 19 Jan to 23 Jan & 07 Jan to 27Jan \\
\hline T7 $(\mathrm{PK})$ & 30 Dec to 14 Jan & 21 Dec to 05 Jan \\
\hline T8 $(\mathrm{NPK})$ & 09 Jan to 19 Jan & \\
\hline
\end{tabular}

Table 4. Effect of fertilizer combinations on malformation frequency

\begin{tabular}{|c|c|c|}
\hline Treatment & Healthy panicles & Malformed panicles \\
\hline T1 (control) & $24 \mathrm{e}$ & $15 \mathrm{a}$ \\
\hline T2 $(\mathrm{N})$ & $26 \mathrm{~d}$ & $7 \mathrm{~b}$ \\
\hline T3 $(\mathrm{P})$ & $25 \mathrm{~d}$ & $6 \mathrm{c}$ \\
\hline T4 $(\mathrm{K})$ & $29 \mathrm{c}$ & $5 \mathrm{~d}$ \\
\hline T5 $(\mathrm{NP})$ & $31 \mathrm{~b}$ & $5 \mathrm{~d}$ \\
\hline T6 (NK) & $28 \mathrm{c}$ & $7 \mathrm{~b}$ \\
\hline T7 $(\mathrm{PK})$ & $30 \mathrm{~b}$ & $8 \mathrm{~b}$ \\
\hline T8(NPK) & $36 \mathrm{a}$ & $5 \mathrm{~d}$ \\
\hline
\end{tabular}


Table 5. Effect of different combination of N, P and K on Malformation physiology of mango Cv. Dusehri

\begin{tabular}{|c|c|c|c|c|c|}
\hline $\begin{array}{c}\text { Treatme } \\
\text { nts }\end{array}$ & $\begin{array}{c}\text { Length of } \\
\text { Healthy Panicle } \\
(\mathbf{c m})\end{array}$ & $\begin{array}{c}\text { Width of } \\
\text { Healthy } \\
\text { Panicle }(\mathbf{c m})\end{array}$ & $\begin{array}{c}\text { Length of } \\
\text { Malformed } \\
\text { Panicle }(\mathbf{c m})\end{array}$ & $\begin{array}{c}\text { Width of } \\
\text { Malformed } \\
\text { Panicle }(\mathbf{c m})\end{array}$ & $\begin{array}{c}\text { Malformati } \\
\text { on Intensity } \\
(\%)\end{array}$ \\
\hline $\begin{array}{c}\mathrm{T} 1 \\
(\mathrm{control})\end{array}$ & $13.28 \mathrm{e} \pm 1.74$ & $10.17 \mathrm{f} \pm 1.99$ & $14.28 \mathrm{a} \pm 2.33$ & $9.24 \mathrm{a} \pm 1.80$ & $\begin{array}{c}85.35 \mathrm{a} \pm \\
2.06\end{array}$ \\
\hline $\mathrm{T} 2(\mathrm{~N})$ & $17.23 \mathrm{~cd} \pm 1.88$ & $13.36 \mathrm{cde} \pm 2.29$ & $13.51 \mathrm{a} \pm 2.09$ & $6.48 \mathrm{ab} \pm 1.90$ & $\begin{array}{c}69.37 \mathrm{~b} \pm \\
1.87\end{array}$ \\
\hline $\mathrm{T} 3(\mathrm{P})$ & $15.37 \mathrm{de} \pm 1.95$ & $12.47 \mathrm{ef} \pm 2.23$ & $13.58 \mathrm{a} \pm 2.22$ & $7.54 \mathrm{ab} \pm 1.90$ & $\begin{array}{c}57.36 \mathrm{~d} \pm \\
2.38\end{array}$ \\
\hline $\mathrm{T} 4(\mathrm{~K})$ & $16.38 \mathrm{cde} \pm 1.86$ & $13.47 \mathrm{cde} \pm 1.95$ & $13.10 \mathrm{a} \pm 2.62$ & $7.55 \mathrm{ab} \pm 1.80$ & $\begin{array}{c}61.47 \mathrm{c} \pm \\
1.70\end{array}$ \\
\hline $\mathrm{T} 5(\mathrm{NP})$ & $19.23 \mathrm{bc} \pm 1.80$ & $16.40 \mathrm{bc} \pm 2.07$ & $11.67 \mathrm{ab} \pm 1.95$ & $7.62 \mathrm{ab} \pm 2.09$ & $\begin{array}{c}61.41 \mathrm{c} \pm \\
2.27\end{array}$ \\
\hline $\mathrm{T} 6(\mathrm{NK})$ & $22.15 \mathrm{~b} \pm 1.90$ & $17.38 \mathrm{ab} \pm 1.92$ & $11.42 \mathrm{ab} \pm 3.01$ & $5.69 \mathrm{~b} \pm 2.10$ & $\begin{array}{c}55.28 \mathrm{~d} \pm \\
2.01\end{array}$ \\
\hline $\mathrm{T} 7(\mathrm{PK})$ & $18.20 \mathrm{~cd} \pm 1.96$ & $14.72 \mathrm{bcd} \pm 1.85$ & $10.63 \mathrm{ab} \pm 2.12$ & $6.85 \mathrm{ab} \pm 1.90$ & $\begin{array}{c}64.27 \mathrm{c} \pm \\
1.87\end{array}$ \\
\hline $\mathrm{T} 8(\mathrm{NPK})$ & $29.40 \mathrm{a} \pm 1.89$ & $20.55 \mathrm{a} \pm 1.97$ & $8.951 \mathrm{~b} \pm 2.360$ & $5.52 \mathrm{~b} \pm 2.01$ & $\begin{array}{c}49.30 \mathrm{e} \pm \\
2.08\end{array}$ \\
\hline
\end{tabular}

Table 6. Regrowth pattern of pruned malformed panicles (\%)

\begin{tabular}{|c|c|c|c|c|}
\hline \multirow{2}{*}{ Treatments } & \multicolumn{2}{|c|}{ Reproductive Pattern } & \multirow{2}{*}{ Vegetative Pattern } & \multirow{2}{*}{ Ceased Growth } \\
\cline { 2 - 3 } & Malformed & Healthy & & \\
\hline T1 (control) & $2.75 \mathrm{c}$ & $1.25 \mathrm{c}$ & $2.25 \mathrm{~d}$ & $93.75 \mathrm{ab}$ \\
\hline $\mathrm{T} 2(\mathrm{~N})$ & $3.25 \mathrm{~b}$ & $0.74 \mathrm{e}$ & $0.55 \mathrm{f}$ & $96.75 \mathrm{a}$ \\
\hline $\mathrm{T} 3(\mathrm{P})$ & $0.278 \mathrm{~g}$ & $1.25 \mathrm{c}$ & $5.44 \mathrm{a}$ & $93.56 \mathrm{~b}$ \\
\hline $\mathrm{T} 4(\mathrm{~K})$ & $2.25 \mathrm{~d}$ & $4.67 \mathrm{~b}$ & $1.54 \mathrm{e}$ & $92.08 \mathrm{ab}$ \\
\hline $\mathrm{T} 5(\mathrm{NP})$ & $3.37 \mathrm{a}$ & $5.54 \mathrm{a}$ & $4.33 \mathrm{~b}$ & $86.76 \mathrm{ab}$ \\
\hline $\mathrm{T} 6(\mathrm{NK})$ & $1.22 \mathrm{e}$ & $1.21 \mathrm{~d}$ & $2.56 \mathrm{c}$ & $95.5 \mathrm{ab}$ \\
\hline $\mathrm{T} 7(\mathrm{PK})$ & $0.75 \mathrm{f}$ & $0.56 \mathrm{f}$ & $2.54 \mathrm{c}$ & $97.25 \mathrm{ab}$ \\
\hline $\mathrm{T} 8(\mathrm{NPK})$ & $2.25 \mathrm{~d}$ & $4.67 \mathrm{~b}$ & $0.55 \mathrm{f}$ & $93.08 \mathrm{a}$ \\
\hline
\end{tabular}

\section{Conclusion}

Mango malformation is enigmatic disease due to nature of disorder and symptoms, their cause and control is not clearly understood for proper control of this malady. Combine fertilizer application effect on the growth physiology of healthy panicles. According to our observation, fertilizer in combination showed the higher morphological attributed in healthy panicles as well as lower malformation intensity in mango (mangifera indica. L) cv. Dusheri than single fertilizer application.

\section{Authors' contributions}

Conceived and designed the experiments: M Azam, R Qadri \& MI Khan, Performed the experiments: $M$ Azam \& R Qadri, Analysed the data: MI Khan, CM Ayub, N Akhter. Contributed materials/analysis/ tools: M Azam, M Khan, R Qadri \& NH Khan, Wrote the paper: M Azam, NH Khan, \& MI Khan.

\section{References}

1. Schlosser SE (1971). Mango malformation: Symptoms, occurrence 
and varietal susceptibility. Plant Prolect. Bull. FAO, 19: 12-14.

2. Chakrabarti DK \& Ghosal S (1985). Effect of Fusarium moniliforme var. subglutions on mangiferin production in the twigs of mango (Mangifera indica L.) J Phytophathol 113: 47-50.

3. Freeman S, Mamon M \& Pinkas $Y$ (1999). Use of gus transformants of $F$. Subglutinans for determining etiology of mango malformation disease. Phytopathol 89: 456-461

4. Usha K, Goswami AM, Sharma HC, Singh B \& Pande PC (1997). Scanning electron microscopic studies on floral malformation. Sci Hortic 71: 127-130

5. Usha K, Gambhir PN, Sharma HC, Goswami AM \& Sing B (1994). Relationship of molecular mobility of water with floral malformation in mango as assessed by NMR. Sci Hortic 59: 291-295

6. Singh RN \& Rathore VS (1983). Changes in moisture content, dry matter accumulation, chlorophyll and nutrients in mango malformation. Indian J Hort 40: 21-25.

7. Muhammad F, Ibrahim M \& Pervez MA (1999). Some physiological aspects of mango malformation. Inter J Agric Biol 1: 94-96.

8. Anonymous. 2017. Agricultural Statistics of Pakistan 2016-17; Government of Pakistan, statistic division Pakistan bureau of statistic, Islamabad, Pakistan

9. Crane JH \& Campbell CW (1994). The Mango. IFAS Fact Sheet HS-2. University of Florida, Florida

10. Misra AK \& Singh VK (2002). Fusarium subglutinans $(F$. moniliforme var. subglutinans) in relation to mango malformation. Indian J Plant Pathol 20: 81-83.

11. Burhan MJ (1991). Mango malformation disease recorded in United Arab Emirates. FAO Plant Prot Bull 39:46-47

12. Minessey FA, Biely MP and El-Fahal A (1971). Effect of iron chelates in correcting malformation of terminal bud growth in mango. Sudan Agric J
6: 71-74

13. Padron SJ (1983). Factors responsible for low yield of mango. Bol. Resenas Port Plantas 10: 37-37.

14. Watt G (1891). A Dictionary of Economic Products of India. Vol. 5, Govt. Printing Press, Calcutta, pp 149.

15. Mallik PC (1963). Mango malformation symptoms, causes and cure. Punjab Hort J 3: 292-299.

16. Kanwar JS \& Kahlon GS (1987). Effect of nitrogen, phosphorus and potassium fertilizer on panicle malformation in mango, Mangifera indica, L. cv. Dashehari. Punjab Hort J 27: 12-16.

17. Kumar J, Singh US and Beniwal SPS (1993). Mango malformation: One hundred years of research. Ann Rev Phytopathol 31: 217-232.

18. Hiffny HAA, El-Barkouki M \& ElBanna GS (1978). Morphological and physiological aspects of the floral malformation of mangoes. Egypt. J. Hort 5: 43-53.

19. Rijkenberg FHJ \& Crookes CA (1984). Mango flower malformation. $S$ Afr Mango Growers' Assoc Yearbook 4:30

20. Ram S \& Yadav YK (1999). Mango malformation: A review. J Applied Hort 1: 70-78

21. Pant RC (2000). Is stress ethylene the cause of mango (Mangifera indica L.) malformation. Physiol Mol Biol Pla 6: 8-14.

22. Bains G and Pant RC (2003). Mango malformation: Etiology and preventive measures. Physiol Mol Biol Pla 9: 41-61.

23. Reddy YTN, Kurian RM, Kohli RR, Gorakh S and Singh G (2000). Effect of nitrogen, phosphorus and potassium on growth, yield and fruit quality of 'Totapuri' mango (Mangifera indica L.). Indian J Agric Sci 70(7): 475-478.

24. Zhou XC, Liu GJ, Yao JW, Ai SY, Yao LX, Zhou XC, Liu GJ, Yao JW, and Yao LX (2001). Balanced fertilization on mango in Southern China. Better Crops International 15(2): 16-20. 
25. Satapathy SK and Banik BC (2002). Studies on nutritional requirement of mango cv. Amrapali. Orissa J Hort 30 (1): 59-63.

26. El-Wakeel HF (2005). Preliminary studies on fertilization of mango trees under U.A.E. conditions: II- Response of Amrapali mango trees to nitrogen and potassium fertilization. Annals Agric Sci 50(2): 563-572.

27. Sarker BC and Rahim MA (2012). Effects of doses and splits of fertilizer application on harvesting time, yield and quality of mango cv. Amrapali. Bangladesh J Agril Res 37(2): 279293

28. Fouad AA, Khalil FM, Ahmed AEM and Abdalla AS (2003). Response of Mabrouka mango trees grown in sandy soil to potassium fertilization. Annals Agric Sci 41(1): 251-259

29. Singh Z, Dhillon BS \& Singh Z (1987). Effect of foliar application of boron on vegetative and panicle growth, sex expression, fruit retention and physicochemical characters of fruits of mango (Mangifera indica L.) cv. Dusehri. Trop Agric 64: 305-308

30. Pandey RM, Rao MM \& Pathak RA (1977). Biochemical changes associated with floral malformation in mango. Sci Hortic 6: 37-44.

31. Bindra OS and Bakhetia DRC (1971). Investigations on the etiology and control of mango malformation. Indian J Hort 28: 80-85.

32. Hafiz, IA, Ahmad S, Abbasi NA, Anwar R, Chatta ZA and Grewal AG (2008). Intensity of Panicle Malformation in mango (Mangifera indica L.) Varieties. Pak J Agric Sci 45(4) 418-423

33. Marloth RH (1947) The litchi in South Africa. I. Varieties and propagation. Farming $S$ Afr 22: 823-830
34. Anwar R, Saleem M, Saleem BA, Ahmad S \& Hussain Z (2005). Mango malformation in relation to leaf nitrogen contents. International conference on mango and Date Palm: Culture and Export 84-88.

35. Marasas WFO, Ploetz RC, Wingfield MJ, Wingfield BD \& Steenkamp ET (2006). Mango malformation disease and the associated fusarium Species. Phytopathol 96(6): 667-672

36. Prasad A, Nirwan RS \& Singh S (1972). Mango malformation: A review of work done at horticultural research institutes, Saharanpur (U.P.). Acta Hort 24: 227-229.

37. Jagirdar SAP \& Jafri NR (1966). Malformation of inflorescence. Agri Pak 17: 357-358.

38. Jagardir SAP \& Shaik MR (1968). Control of malformation of mango inflorescence. souvenir mango and summer fruit show, Mirpur Khas, West Pakistan pp 124-126

39. Thakur AS, Vaishampayan SM \& Shukla A (2000). Effect of varieties, nutrient and direction on the incidence of floral and vegetative malformation in grafted mango. Crop Res 20(3): 494-499.

40. Zora S, Dhillon BS \& Arora CL (1991). Nutrient levels in malformed and healthy tissues of mango (Mangifera indica L.). Plant Soil 133(1): 9-15

41. Ahmad F, Hafiz IA, Asi AA, Ahmad S \& Khan M (2002). Mango varietal susceptibility to malformation and its control. Asian J Plant Sci 2: 158-159.

42. Khan MD \& Khan AH (1960). Some studies on malformation of mango inflorescence in West Pakistan. Punjab Hort J 3: 229-234. 